\title{
The effectiveness of Pencak Silat to change teenage personalities
}

\author{
Tjung Hauw Sin ${ }^{1}$, Nurul Ihsan ${ }^{2}$ \\ ${ }^{12}$ Universitas Negeri Padang, Indonesia
}

\section{Article Info}

Article history:

Received Des 16th, 2019

Revised Jan 22nd, 2020

Accepted Feb 1st, 2020

\section{Keyword:}

Pencak silat

Teenager

Behavior

\begin{abstract}
This study aims to look at the effect of martial arts exercises on changes in adolescent personality. The sample of this study was Yadika Lubuklinggau High School students who participated in pencak silat extracurricular activities, totaling 22 people. The sampling technique is a total sampling technique. The hypothesis proposed in this study is that martial arts exercises provide a significant influence on changes in adolescent personality. The design of this study is one group pretest-posttest. Data collection techniques using a questionnaire with Likert Scale. The data in this study are the answers of the sample parents regarding their daily personalities both before and after pencak silat training. Hypothesis testing with a t-test at a significant level of $0.05 \%$. Based on testing the research hypothesis using the t-test statistical analysis it is known that the t-value is 3,227 , while the t-table value is 1,720 . Thus, it can be concluded that the hypothesis proposed in this study was accepted. The conclusion that can be drawn in this study is that martial arts exercises provide effects on changes in adolescent personality.
\end{abstract}

(C) 2020 The Authors. Published by Indonesian Institute for Counseling Education and Therapy (IICET). This is an open access article under the CC BY license (https://creativecommons.org/licenses/by/4.0/)

\footnotetext{
Corresponding Author:

Tjung Hauw Sin,

Universitas Negeri Padang

Email: thj_sin@yahoo.com
}

\section{Introduction}

The purpose of sports activities includes several aspects, namely for education, for recreation, for physical fitness and for achievement (Ihsan \& Suwirman, 2018). Sports are part of the activities carried out by humans. The basic concepts of sports vary, including: play, Physical education, Sport, recreation, and dance (M. N. Sari, 2019). Of the various types of sports that are quite popular in society today one of them is martial arts. Viewed from the aspect of sports, then the role and function of pencak silat as one of them is to equip members of their schools with self-defense skills, equip their members with material materials, norms and other positive values (Juliardy, 2014). Pencak silat is one of the Indonesian martial arts which has long been developed in all corners of the country, even to foreign countries (Kumaidah, 2012). Pencak silat enthusiasts are not only limited to certain ages, but have been in demand by various levels of age, ranging from children, adolescents, adults to the elderly. At present, pencak silat has entered the educational curriculum which is included in the aspects of games and sports (Ihsan, Sepriadi, \& Suwirman, 2018).

Each branch of martial arts has special characteristics that are different from one another. In the pencak silat branch, these characteristics are outlined in the characteristics of pencak silat (general and special characteristics) which refer to the understanding and elements of pencak silat (Masruri, 2016). In essence, pencak silat is the work of ancestral manners which has been developed from generation to generation, until it reaches its form as it is today. (Shahrudin, 2018). Pencak silat is also a combination of spirituality, reason, will and awareness of his nature as a personal and social creature created by God (Nur, 2017). The roles and functions of pencak silat cover four aspects of life, namely: art, martial arts, 
sports and education (Mardotillah \& Zein, 2017; Prastyana, 2016). Specifically education facilities, then through the arts, sports and martial arts, pencak silat also teaches noble character, aims to develop traits and attitudes that are always devoted to God Almighty, have grace, self confidence, discipline, love for the nation and homeland, brotherhood, control, responsibility and pursuit of social solidarity (Kholis, 2016). In the mental and spiritual aspects of pencak silat build and develop the personality and noble character of a person (Ihsan, 2014).

The adolescent phase is the transition phases (Diahloka, 2012). It is said to be a transition phase because during this period adolescents are no longer said to be children, and have not yet been said to be adults (Monks, 2004). Physical changes in adolescents are almost always accompanied by changes in attitudes and behavior. One consequence of this change is that teenagers often display attitudes and behaviors that are not understood by parents (Dewi \& Susilawati, 2016; Jahja, 2011).

Various impacts that will be felt by parents, the environment and society on adolescent behavior. Among them is the frequent occurrence of brawls, like being alone, refuting parents and so on is part of the impact of negative behavior caused by physical growth. By considering the impact that will be faced on adolescent growth, it is necessary to prepare a method of handling this problem. This is because if not fulfilled the needs of adolescents, it can be sure that various undesirable things will happen (Sumara, Humaedi, \& Santoso, 2017). in the end it can harm the teenager himself. One solution is to provide opportunities for teenagers to fill their daily activities by practicing pencak silat.

In essence, pencak silat is the work of ancestral manners that has been developed from generation to generation, until it reaches its form as it is today. Pencak silat is also a combination of spirituality, reason, will and awareness of his nature as a personal and social creature created by God (Mulyono. 2013). Specifically education facilities, then through the arts, sports and martial arts, pencak silat also teaches noble character, aims to develop traits and attitudes that are always devoted to God Almighty, have grace, self confidence, discipline, love for the nation and homeland, brotherhood, control, responsibility and social solidarity pursuing progress and defending honesty, truth and justice (Andi Mappiare, 2018).

Based on the teachings of manners, physical skills taught in martial arts have qualifications as martial arts, arts and sports that provide skills, comfort and health to everyone. In the mental and spiritual aspects of pencak silat build and develop the personality and noble character of a person (Adyanto, Muhajir, \& Fajriyah, 2018; Kholis, 2016; Sinulingga, 2018). When viewed from the roles and functions of pencak silat that have been stated, the research will look at the changes in the attitude and personality of adolescents who follow martial arts training. Researchers will focus more research on the role of pencak silat as a means of forming personality for adolescents (Alivia, 2016; Rosidi, 2017).

Personality comes from the word personality which comes from the word persona (Latin) which means mask or mask, which is a face mask that is often used by stage performers, which means to describe a person's behavior, character or personality (H. Sari \& Shabri, 2016). Personality is a unique and unique aspect of a person's behavior, which can affect the person's ability to adapt to the environment (Hildayani, Sugianto, Tarigan, \& Handayani, 2014; Sujiono, Zainal, Rosmala, \& Tampiomas, 2014). Personality is also defined as the characteristics of a person that causes consistency of feelings, thoughts, and behavior (Widiantari \& Herdiyanto, 2013). Every person has a personality pattern that is not always the same, even though they have the same origins or descendants. Thus people who get along in different societies will produce a process of forming different personalities (Mu'arif, 2016).

Personality is something that is real from someone related to individual position (Hadi, 2017). This means, behavior is everything that is displayed in the form of motor movement by someone. Behavior is a collection of responses that becomes very complex which is always related to the stimulus, just as a response is always related to the stimulus (Gunarti \& Muis, 2014). From some of the definitions above it can be concluded that personality is anything that is displayed by humans that can be assessed and observed by others or it can be said that personality is the embodiment or self-actualization of a person against the stimulus that comes. Some opinions state that personality is a reflection of daily behavior. To be able to understand behavior, it is necessary to first understand a number of theories that address this issue (Jones, 2010).

The noble values contained in the sport are legacies that deserve to be maintained, and one of them is the noble values contained in pencak silat (Ihsan \& Suwirman, 2018). The values contained in the sport, as well as its influence for the sport actors are also found in pencak silat. This can be seen through the role of pencak silat which teaches personal recognition as a human being or creature who believes in the 
existence of a higher power, namely God Almighty. Pencak silat as a spiritual / mystical teaching is given to students who have advanced in their martial arts learning. The goal is to improve students' character or nobility. So that in the end pencak silat has the aim to realize harmony / balance / harmony around to increase faith and piety to God Almighty, in order to fill the national development of Indonesia in realizing Indonesian people who are fully Pancasilais.

Pencak silat martial arts are smooth, flexible sports that are full of art like soft power. But if you get a threat, after trying to dodge, parry and still be threatened, the pesilat will take self-defense and attack (Ihsan, Yulkifli, \& Yohandri, 2018). Generally, pencak silat teaches personal self-introduction as a human being or creature who believes that there is a higher power, namely God Almighty. Based on the above opinion, it can be said that in addition to equipping martial artists with martial arts abilities, as well as forming, fostering the physical and spiritual perpetrators, the teachings in pencak silat instill sports values that are universal to the culprit. In addition, martial arts also emphasizes to the perpetrators how to behave to themselves, others and interpret themselves as creatures created by God Almighty (habluminannas wa hablumminallah).

Teenagers can be explained in two ways, namely by explaining their definitions and age periods. In terms of definition, adolescents can be said to be individuals who have experienced puberty or have the functioning of the hormone reproduction so that women experience menstruation and men have wet dreams. In terms of adolescence ranges from 13 to 21 years (Hartati \& Respati, 2012; Safitri \& Hidayati, 2013). Teenage phases based on biological views range from ages 14 to 21 years. Meanwhile according to Yusuf (2008) quoting Konapa's opinion of adolescence including early adolescents aged 12-14 years (Pritaningrum \& Hendriani, 2013), middle adolescents aged 15-18 years and late teens aged 19-22 years. If seen from the age range in adolescence and associated with school age, adolescents can be classified as middle school age (junior and senior high school). Specifically in this study, adolescents who will be the object of research are school students who sit in classes X and XI whose ages range between 15-18 years. This age belongs to the middle adolescent group.

Adolescence is also referred to as the social hunger period (social thirst), which is marked by the desire to get along and be accepted in their peer group environment (Afrianti, 2017). Rejection from peer groups can cause frustration and make him a loner, isolated and feel inferior. But on the contrary if a teenager can be accepted by his peers and even become an idol of course he will feel proud and have honor in him (Wati, 2016). Adolescent social behavior problems do not only occur with peer groups, but can also occur with parents and other adults, including with teachers at school. This is caused in adolescence, especially early adolescents will be marked by ambivalent desires. On the one hand there is a desire to release dependency and can make their own choices. On the other hand he still needs parents, especially economically.

The occurrence of various negative behaviors according to Prayitno (2006) is caused by environmental influences that do not support, respect and acknowledge the existence of those who are developing. This is based on the fact that adolescents who are looking for identity are often less accepted by adults and for children themselves are considered to be great to follow their environment (Muthohar, 2016; Nurgiyantoro, 2011). Thus, adolescents are in a difficult position to do. Eventually adolescents show their existence through actions that can attract the attention of others. These actions tend to lead to negative ones, such as over acting and so forth. Understanding behavior is a necessity that cannot be abandoned, because understanding behavior is the main capital in the relief effort (Yasin, 2013). By being fully understood, individuals will feel accepted as they are and can then openly express various problems".

The values and norms that apply in society are usually not written. And therefore, behavior can only be assessed through a number of indicators. In this study, the author tries to compile indicators that can be used as a benchmark in providing an assessment of individual behavior based on expert opinion. The following are indicators that can be seen in representing behavior, namely Motive, Emotion, Social Interaction, Social Interaction, Faith and Devotion to God, Self Concept.

\section{Method}

This study uses quasi-experimental research methods with One Group Pretest-Posttest Design research design. In accordance with the problems and objects to be studied, then in this study the population will be high school students who participate in pencak silat extracurricular activities. The number of samples amounted to 22 people with purposive sampling technique. This technique is done based on researchers' 
own considerations in determining the number of samples (Margono, 2003: 128). In measuring adolescent behavior, the instrument used is through a questionnaire / questionnaire with a Likert scale. Treatment was carried out for 16 meetings with the design of the basic pencak silat curriculum, treatment in the form of pencak silat exercises.

In accordance with the aims and objectives of this study, the data collection was carried out with the research design of the One Group Pretest-Posttest Design. Initial Test (Pretest) and Final Test (Posttest). The purpose of this exercise is to see changes in student behavior (samples) after participating in martial arts exercises before and after practice. In accordance with the objectives and hypotheses in this study, then testing the data that has been obtained will be analyzed through data analysis techniques in accordance with the type and purpose of the research that is using inductive statistical techniques using $t$ test (Sumber: Arikunto, 2005: 398)

\section{Result and Discussion}

Preliminary test results

Figure 1. Histogram Distribution of initial sample tests The results of this study were obtained from a questionnaire distributed to respondents (sample parents). This questionnaire contains questions relating to variables about the behavior of adolescents (samples) on a daily basis based on the indicators that have been designed. As for the indicators are 1) Relating to adolescent motivation, 2) Relating to adolescent emotions, 3) Relating to interaction adolescent social, (3). Associated with the understanding of adolescents as creatures of God Who is One, and 5) Associated with adolescent self-concept. Data is taken before and after the sample gets treatment. The following table is a description of each data obtained in this study (preliminary test and final test):

Table 1. Description of initial test data

\begin{tabular}{lll}
\hline & Statistik & Tes awal \\
\hline $\mathbf{N}$ & & 22 \\
\hline Mean & 225.1818 \\
\hline Median & 227 \\
\hline Modus & 203 & \\
\hline SD & 22.6561 \\
\hline Var & 513.2987 \\
\hline$\sum$ & 4954 & \\
\hline
\end{tabular}

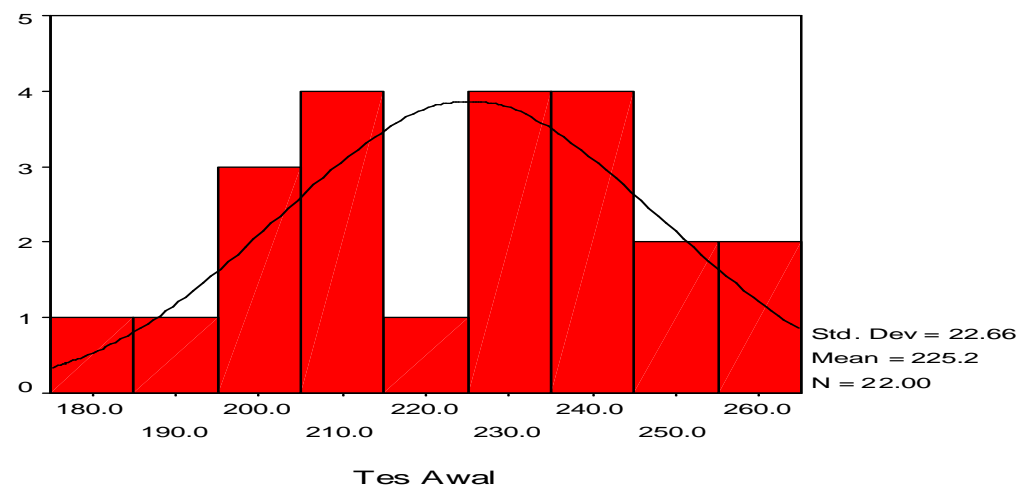

Figure 1. Histogram distribution of initial sample tests

Based on the table above, it is known that the initial test results from 22 samples obtained an average value of 225.18, a median of 227, mode 203, standard deviation of 22.66, variance of 513.30 and the total number of initial test scores of the sample is 4954 . Based on the distribution, the distribution can be concluded data tends to be normally distributed. 
Final test result

Final test data in the form of parents' answers to the questionnaire that contains about the daily behavior of children (samples). Similar to the initial test data, then the final test data is processed. Data processing was performed using SPSS version 11. The description of the initial test results can be seen in the following table:

Table 2. Description of the final test data

\begin{tabular}{lll}
\hline & Statistik & Tes akhir \\
\hline $\mathbf{N}$ & 22 & \\
mean & 242.3182 & \\
median & 237 & \\
modus & 233 & \\
SD & 15.78844 & \\
var & 249.2749 & \\
$\sum$ & 5331 & \\
\hline
\end{tabular}

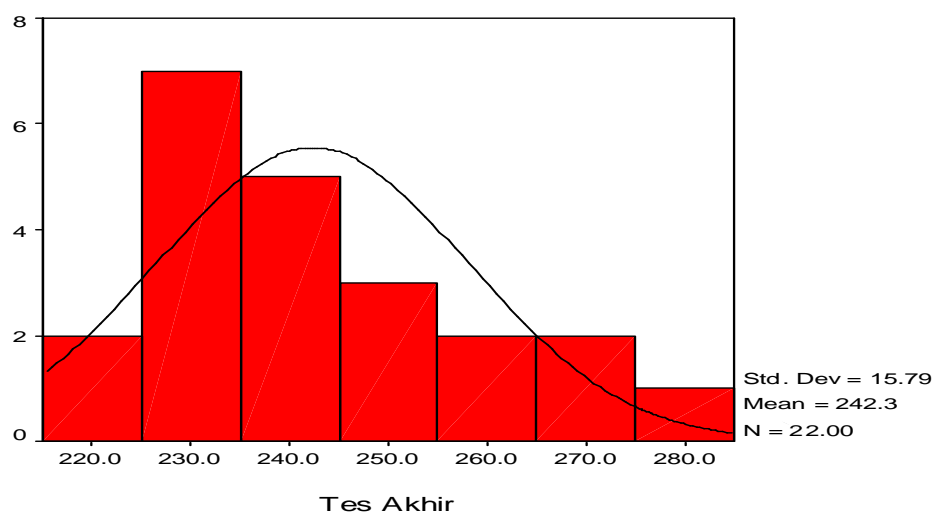

Based on the table above, it is known that the final test results from 22 samples obtained an average value of 242.32, a middle value of 237, a standard 233 deviation mode of 15.79 , variance of 249.27 and the total number of initial test scores of the sample is 5331. Based on the distribution, it can be concluded that the distribution of data tends to be normally distributed.

Testing the difference is between the mean value between the initial test and the mean value of the final test. To see whether there is an improvement carried out using t-test techniques (Arikunto, 2005: 395). To further facilitate further discussion, we need a table which is a summary of all calculations of the proposed hypothesis, it is necessary to help the following table:

Table 3. Recapitulation of Initial and Final Test Data

\begin{tabular}{|c|c|c|c|c|c|c|}
\hline Data & Data & Mean & SD & $\sum \mathbf{D}$ & $\overline{\mathbf{D}}$ & $\sum \mathbf{D}^{2}$ \\
\hline Preliminary test & 4954 & 225.18 & 22.56 & \multirow{2}{*}{377} & \multirow{2}{*}{17.136} & \multirow{2}{*}{19485} \\
\hline Final test & 5331 & 242.32 & 15.79 & & & \\
\hline
\end{tabular}

From these calculations, a t-count value of 3,227 was obtained. After knowing the t-value, then the next thing to do is look for the t-table at the significance level of 0.05 and $\mathrm{dk} n-1$. The $\mathrm{t}$-table value at the 0.05 significance level with $\mathrm{dk} 21$ is 1.721 .

After being compared, it is seen that the t-value is 3,227 greater than the t-table value, which is 1,720 . Thus it can be concluded that the proposed hypothesis is accepted. To better understand the following, a summary of the results of the calculation is presented.

Table 4. Summary of calculation of hypothesis tests

\begin{tabular}{cccc}
\hline Test & $\mathbf{t}-$ count & $\mathbf{t}_{\text {table }}$ & Conclusion \\
\hline Preliminary and Final test & 3.227 & 1.72 & Significant \\
\hline
\end{tabular}


Based on the calculations that have been made known that there is a change in the behavior of adolescents who follow martial arts training. When seen the average value obtained from the initial test that is equal to 225.18 , and the average value of the final test that is equal to 242.32 , then an increase of 17.14 is known. This figure is an increase (change) in adolescent behavior after participating in martial arts training.

As has been explained in the previous section that pencak silat is a heritage of the nation's ancestors which should not only be preserved. But more than that, pencak silat in which there are noble values of character and shape and foster the character and personality of the culprit. For this reason, the existence of pencak silat should be a concern of the Indonesian people.

In addition to equipping the culprit with strong martial arts abilities, pencak silat also equips the culprit with social teachings. More than that, in essence pencak silat is a form of human servitude as the creation of God Almighty. In essence, pencak silat is a container for the formation of the personality of the perpetrators, both in terms of relating to the community and as a form of actualization of the obedience of the perpetrators with his creator.

Teenagers are one of the critical phases that humans go through in a series of their lives. In this phase, so many problems arise. The various problems that arise are a result of physical growth and development that are not addressed by the teenage environment. Emotions that are less stable, often aloof, contradictory, etc. are some of the problems that the environment must face as a consequence of instability in adolescents. Psychological turmoil if not responded wisely by the environment, it will have a negative impact on adolescents.

The emergence of behaviors that act in accordance with the values and norms that apply in the midst of the community. When seen the average value obtained from the initial test is 225.18 , and the average value of the final test is 242.32 , it is known an increase of 17.14. This figure is an increase (change) in adolescent behavior after participating in martial arts training. Based on the calculations that have been carried out proficiency level, it is known that there is a change in the behavior of adolescents who follow martial arts training. In this case, the change in question is a change for the better. However, when viewed from individuals, it is known that not all of them (samples) experienced changes in behavior after participating in pencak silat training for 16 meetings. This indicates that pencak silat has no effect on overall changes in sample behavior.

When viewed from the indicators presented in this study, then through pencak silat adolescents can form a positive motivation within themselves. By having positive motivation, adolescents will be able to generate enthusiasm to do positive things too. And finally, through this motivation, adolescents can reach their goals.

In addition to creating positive motivation, pencak silat is also able to form positive self-concepts and emotions in adolescents as well. Confidence, courage to act, and view things from the positive side are the targets of pencak silat training. Able to be calm, not easily angry and respect each other merupkan characteristics of a true fighter. By having a positive self-concept and stable emotions, adolescents will be able to explore all abilities within themselves without fear. So that in the end teenagers are able to innovate and create more.

Besides that, pencak silat also creates individuals who understand the ways to relate to fellow humans and relate to His creator. This is because pencak silat does not only equip with self-defense skills, but on its behalf pencak silat teaches the perpetrators of the nature of their existence in the midst of society and the nature of individuals as creatures created by God Almighty. Through his understanding of the nature of himself in the midst of society and in the eyes of his creator, the individual can establish interactions in accordance with the provisions that govern them. Both the provisions in interacting with fellow human beings, as well as interactions with God Almighty. 


\section{Conclusion}

Conclusion Based on the findings in this study referring to the statistical calculations it turns out that the t-count value of 3,227 is greater when compared to the $t$-table value of 1,720 . This means that the hypothesis proposed in this study was accepted. Thus it can be concluded that pencak silat training can significantly influence changes in adolescent behavior towards a more positive direction.

\section{References}

Adyanto, S. P., Muhajir, M., \& Fajriyah, K. (2018). Karakteristik Siswa Anggota Ekstrakulikuler Pencak Silat Ditinjau dari Nilai Karakter. Jurnal Sinektik, 1(1), 46-52.

Afrianti, N. (2017). Profil kecerdasan sosial siswa SMA di Kota Bandung dan implikasinya terhadap penyelenggaraan layanan bimbingan konseling. Jurnal Ilmiah Psikologi Terapan, 5(1), 40-59.

Alivia, L. A. (2016). Peranan Pendidikan Berbasis Islam dalam Pembentukan Karakter Siswa di SD IT Baitul Jannah Bandar Lampung Tahun Pelajaran 2015/2016.

Andi Mappiare, A. (2018). Meramu Model Konseling Berbasis Budaya Nusantara: Kipas.

Dewi, N., \& Susilawati, L. (2016). Hubungan antara kecenderungan pola asuh otoriter (authoritarian parenting style) dengan gejala perilaku agresif pada remaja. Jurnal Psikologi Udayana, 3(1), 108-116.

Diahloka, C. (2012). Pengaruh Sinetron Televisi Dan Film Terhadap Perekmbangan Moral Remaja. Reformasi: Jurnal Ilmiah Ilmu Sosial dan Ilmu Politik, 2(1).

Gunarti, W., \& Muis, A. (2014). Metode Pengembangan Perilaku dan Kemampuan Dasar AUD.

Hadi, I. A. (2017). Pentingnya Pengenalan Tentang Perbedaan Individu Anak Dalam Efektifitas Pendidikan. INSPIRASI: Jurnal Kajian dan Penelitian Pendidikan Islam, 1(1), 71-92.

Hartati, L., \& Respati, W. S. (2012). Kompetensi interpersonal pada remaja yang tinggal di panti asuhan asrama dan yang tinggal di panti asuhan cottage. Jurnal Psikologi Esa Unggul, 10(02), 126613.

Hildayani, R., Sugianto, M., Tarigan, R., \& Handayani, E. (2014). Psikologi perkembangan anak.

Ihsan, N. (2014). The Analysis of Physical Condition, Will Pencak Silat Construction Training Center Students (PPLP) of West Sumatra.

Ihsan, N., Sepriadi, S., \& Suwirman, S. (2018). Hubungan Status Gizi Dan Motivasi Berprestasi Dengan Tingkat Kondisi Fisik Siswa Pplp Cabang Pencak Silat Sumatera Barat. Sporta Saintika, 3(1), 410422.

Ihsan, N., \& Suwirman, S. (2018). Sumbangan Konsentrasi terhadap Kecepatan Tendangan Pencak Silat. Media Ilmu Keolahragaan Indonesia, 8(1), 1-6.

Ihsan, N., Yulkifli, Y., \& Yohandri, Y. (2018). Instrumen Kecepatan Tendangan Pencak Silat Berbasis Teknologi. Jurnal Sosioteknologi, 17(1), 124-131.

Jahja, Y. (2011). Psikologi perkembangan: Kencana.

Jones, P. (2010). Pengantar Teori-Teori Sosial: Dari Fungsionalisme hingga Post-modernisme: Yayasan Pustaka Obor Indonesia.

Juliardy, A. (2014). Melalui Variasi Pembelajaran dalam Meningkatkan Hasil Belajar Tendangan Busur Pencak Silat Siswa Kelas Vii Smp Cerdas Murni Deli Serdang Tahun Ajaran2013/2014. UNIMED.

Kholis, M. N. (2016). Aplikasi Nilai-Nilai Luhur Pencak Silat Sarana Membentuk Moralitas Bangsa. Jurnal Sportif $\mid$ Vol, 2(2).

Kumaidah, E. (2012). Penguatan Eksistensi Bangsa Melalui Seni Bela Diri Tradisional Pencak Silat. HUMANIKA, 16(9).

Mardotillah, M., \& Zein, D. M. (2017). Silat: Identitas Budaya, Pendidikan, Seni Bela Diri, Pemeliharaan Kesehatan. Jurnal Antropologi: Isu-Isu Sosial Budaya, 18(2), 121-133.

Masruri, A. (2016). Penyusunan Norma Tes Keterampilan Pencaksilat terhadap Gerakan Tendangan bagi Atlet Pemula Kategori Remaja di Pusat Pembinaan Latihan Pelajar Jawa Tengah. Universitas Negeri Semarang.

Monks, F., . dkk. (2004). Psikologi perkembangan: Pengantar dalam berbagai bagiannya.

Mu'arif, S. S. (2016). Pembinaan Pergaulan Remaja melalui Kegiatan Kerohanian Islam (Rohis) di SMA Negeri Jatilawang Kabupaten Banyumas (Doctoral Dissertation, Iain Purwokerto). IAIN Purwokerto.

Muthohar, S. (2016). Antisipasi degradasi moral di era global. Nadwa, 7(2), 321-334.

Nur, S. (2017). Filosofi gerakan pembukaan pencak silat persaudaraan setia hati terate (PSHT) dan implikasinya terhadap pengembagan personality (Studi kasus pada UKM beladiri di IAIN Ponorogo). IAIN Ponorogo.

Nurgiyantoro, B. (2011). Wayang dan pengembangan karakter bangsa. Jurnal Pendidikan Karakter, 1(1). 
Prastyana, B. R. (2016). Peran Exstrakurikuler Pecak Silat Dalam Meminimalisir Kenakalan Remaja di Sekolah. Buana Pendidikan: Jurnal Fakultas Keguruan dan Ilmu Pendidikan, 12(22), 28-48.

Pritaningrum, M., \& Hendriani, W. (2013). Penyesuaian diri remaja yang tinggal di Pondok Pesantren Modern Nurul Izzah Gresik pada tahun pertama. Jurnal Psikologi Kepribadian dan Sosial, 2(3), 134143.

Rosidi, A. (2017). Strategi Dakwah Organisasi Persaudaraan Setia Hati Terate melalui Pencak Silat (Studi Kasus di Ranting Gunungsari Kecamatan Gunungsari Kabupaten Lombok Barat). Universitas Islam Negeri Mataram.

Safitri, Y., \& Hidayati, E. (2013). Hubungan Antara Pola Asuh Orang Tua Dengan Tingkat Depresi Remaja di SMK 10 November Semarang. Jurnal Keperawatan Jiwa, 1(1).

Sari, H., \& Shabri, S. (2016). Hubungan Tipe Kepribadian dengan Motivasi Belajar pada Mahasiswa Kurikulum Berbasis Kompetensi Fakultas Keperawatan Universitas Syiah Kuala. Idea nursing journal, 7(2), 1-12.

Sari, M. N. (2019). Pengembangan latihan koordinasi gerak dasar senam Zumba bagi member di Sanggar Kebugaran Ilmu Keolahragaan Universitas Negeri Malang (SKIK UM). SKRIPSI Mahasiswa UM.

Shahrudin, H. (2018). Metode Dakwah dalam Pencak Silat Persaudaraan Setia Hati Terate (PSHT) DI KOMISARIAT IAIN Surakarta. IAIN SURAKARTA.

Sinulingga, G. (2018). Upaya Pelestarian Nilai-Nilai Kearifan Lokal dalam Budaya Pencak Silat Melalui O2SN.

Sujiono, Y. N., Zainal, O. R., Rosmala, R., \& Tampiomas, E. L. (2014). Metode pengembangan kognitif.

Sumara, D. S., Humaedi, S., \& Santoso, M. B. (2017). Kenakalan remaja dan penanganannya. Prosiding Penelitian dan Pengabdian kepada Masyarakat, 4(2).

Wati, I. (2016). Peningkatan Kerjasama pada Materi Perubahan Benda Menggunakan Model Pembelajaran Cooperative Tipe STAD. Jurnal Penelitian Pendidikan Indonesia, 1(1).

Widiantari, K. S., \& Herdiyanto, Y. K. (2013). Perbedaan intensitas komunikasi melalui jejaring sosial antara tipe kepribadian ekstrovert dan introvert pada remaja. Jurnal Psikologi Udayana, 1(1).

Yasin, F. (2013). Penumbuhan kedisiplinan sebagai pembentukan karakter peserta didik di madrasah. elhikmah(1). 